\title{
Analisis Market Share Perbankan Syariah di Indonesia
}

\author{
Ahmad Rifqi Hidayat, Aidha Trisanty \\ Universitas Islam Indonesia, Yogyakarta \\ *Correspondence address: aidha.trisanty@uii.ac.id
}

\section{㟒勒}

ISSN: $1979-4703(\mathrm{p})$

ISSN: 2527-9726(e)

Keywords:

Market Share, Perbankan

Syariah, Indonesia

\begin{abstract}
A B S T R A C T
The majority of Indonesia's population is Muslim. Ideally, the development of Islamic banking in Indonesia runs significantly, but the facts show that the market share of Islamic banks is still relatively small. This article aims to analyze the market share of Islamic banking in Indonesia. This study uses a descriptive quantitative approach. The data collection method used is the non-communication method, namely in the form of observation, literature review and experimentation through secondary data. Based on the results of the analysis and discussion, it shows that the market share of Islamic banking in Indonesia is still relatively low. The factors causing the low market share of Islamic banks and the improvement strategy are focused on three sides: Islamic banks' internal elements, aspects of government, regulators, and characteristics of society. In the future, there is a need for strategic steps from all parties to increase the market share of Islamic Banking in Indonesia.
\end{abstract}

\section{A B S T R A K}

Penduduk Indonesia mayoritas beragama Islam, idealnya perkembangan perbankan syariah di Indonesia berjalan signifikan. Namun demikan, fakta menunjukkan bahwa pangsa pasar bank syariah masih relative kecil. Artikel ini bertujuan untuk menganalisis market share Perbankan Syariah di Indonesia. Studi ini menggugnakan pendekatan kuantitatif deskriptif, dengan metode pengumpulan data yang digunakan adalah non communication method, yakni berupa observasi, kajian literatur dan eksperimen melalui penggunaan data sekunder. Berdasarkan hasil analisis dan pembahasan menunjukkan bahwa market share Perbankan Syariah di Indonesia masih cukup rendah. Faktor penyebab rendahnya market share Bank Syariah dan strategi pengingkatan difokuskan pada tiga sisi yaitu berdasar elemen internal bank syariah, elemen pemerintah, regulator, dan elemen masyarakat. Kedepan, perlu adanya langkah strategis dari semua pihak untuk meningkatkan market share Perbankan Syariah di Indonesia.

\section{Pendahuluan}

Bank Syariah lahir di Indonesia setelah dikeluarkannya Undang-Undang No. 7 Tahun 1992 tentang bank berdasarkan prinsip bagi hasil, yang kemudian direvisi dengan Undang-Undang No. 10 Tahun 1998 tentang Perubahan Atas Undang-Undang No. 7 Tahun 1992 dalam bentuk sebuah bank yang beroperasi dengan prinsip syariah yang 


\section{At-Taqaddum}

Vol. 12 No. 2 (2020) 183-200

ditandai dengan berdirinya Bank Muamalat Indonesia pada tahun 1991 dan memulai kegiatan operasinya pada bulan Mei 1992. Dengan lahirnya Undang-Undang tersebut, maka landasan hukum bank syariah menjadi lebih jelas dan kuat baik dari segi kelembagaan maupun landasan operasionalnya. Dari segi jaringan, pada Desember 2019 tercatat terdapat 14 (empat belas) Bank Umum syariah (BUS), 20 (dua puluh) Unit Usaha Syariah (UUS), dan 164 (seratus enam puluh empat) Bank Pembiayaan Rakyat Syariah yang sudah terdaftar di Bank Indonesia (Statistik Perbankan Syariah, 2019).

Secara umum kinerja perbankan syariah dapat dilihat dari tiga indikator, yaitu jumlah aset, dana pihak ketiga (DPK) yang terkumpul, serta banyaknya pembiayaan yang disalurkan oleh perbankan. Dari periode tahun 2014, pertumbuhan aset Bank Umum Syariah (BUS) menunjukkan tren positif. Total aset pada Desember 2016 adalah sebesar Rp 254.184 milyar rupiah, naik menjadi Rp. 350.363 milyar rupiah pada Desember 2019. Hal tersebut juga terjadi pada Unit Usaha Syariah (UUS) dimana pada periode tahun 2016 pertumbuhan aset Unit Usaha Syariah (UUS) juga menunjukkan tren positif. Total aset pada Desember 2016 adalah sebesar Rp 102.320 milyar rupiah, naik menjadi Rp. 174.200 milyar rupiah pada Desember 2019.

Secara historis pertumbuhan perbankan syariah cukup pesat, namun masih jauh jika dibandingkan dengan perbankan konvensional. Sampai dengan Juni 2019, pangsa pasar (market share) masih berada pada angka 5,95 persen masih jauh dibawah market share perbankan konvensional. Hal ini dapat dilihat dari beberapa indikator utama market share yaitu; asset, pembiayaan yang disalurkan (penyaluran dana) dan Dana Pihak Ketiga (DPK) yang dihimpun (OJK, 2020). Perbandingan aset, PYD dan DPK bank syariah dan bank konvensional per Desember 2019 dapat dilihat pada tabel 1 berikut ini.

Tabel 1. Perbandingan Asset, Penyaluran Dana dan DPK Bank Syariah dan Bank Konvensional (dalam juta rupiah) pada Desember 2019

\begin{tabular}{lllll}
\hline Jenis Bank & Aset & Penyaluran Dana & DPK & $\begin{array}{l}\text { Jumlah } \\
\text { Bank }\end{array}$ \\
\hline Bank Syariah & 538.322 & 365.125 & 330.508 & 198 \\
\hline Bank Konvensional & 8.712 .597 & 8.424 .648 & 6.962 .790 & 1.636 \\
\hline
\end{tabular}

Sumber: Data diolah, 2020

Data Statistik Perbankan Syariah diatas menunjukkan perbandingan antara aset, penyaluran dana dan DPK antara perbankan syariah dan perbankan konvensional. Dari sisi aset, dapat dilihat bank konvensional memiliki jumlah asset enam belas kali lipat lebih tinggi dibanding bank syariah, sedangkan penyaluran dan DPK bank konvensional masing-masing lebih tinggi sebesar dua puluh tiga kali dan dua puluh satu kali disbanding bank Syariah. Hal ini menunjukkan sebenarnya pangsa pasar perbankan syariah seharusnya dapat ditingkatkan jauh lebih besar lagi, terlebih dengan latar belakang penduduk Indonesia yang sebagian besar adalah muslim. Berdasarkan hal tersebut, tujuan studi ini adalah untuk mengetahui bagaimana market share bank Syariah di Indonesia, dan 
mengidentifikasi strategi apa yang dapat dilakukan untuk meningkatkan market share tersebut.

\section{Tinjauan Pustaka}

Bank Syariah merupakan bank yang beroperasi sesuai dengan ketentuan syariat agama Islam. Bank Syariah, atau biasa disebut Islamic Bank di negara negara lain, di Indonesia bersemat logo $\mathrm{iB}$ pada brand masing-masing bank syariah berbeda dengan bank konvensional pada umumnya. Perbedaan utamanya terletak pada landasan operasi yang digunakan (Sodikin, 2020). Market Share (Pangsa Pasar) adalah persentase dari keseluruhan pasar untuk sebuah kategori produk atau service yang telah dipilih dan dikuasai oleh satu atau lebih produk atau service tertentu yang dikeluarkan sebuah perusahaan dalam kategori yang sama menurut Gunara dalam Asmoro (2018) Secara sederhana, market share (pangsa pasar) merupakan persentase dari luasnya total pasar yang dapat dikuasai oleh suatu perusahaan. Market share dalam praktik bisnis merupakan acuan, karena perusahaan dengan nilai pangsa pasar yang lebih baik akan menikmati keuntungan dan penjualan produk dengan lebih baik pula ketimbang pesaingnya. Total aset adalah salah satu indikator dalam perhitungan market share. Snapshot yang dipakai oleh Otoritas Jasa Keuangan memakai indikator lain yang adalah bagian dari aset seperti total PYD (Pembiayaan Yang Disalurkan), total DPK (Dana Pihak Ketiga), jumlah institusi dan jumlah kantor.

Dalam pembicaraan pangsa pasar tentunya tidak terlepas dari masyarakat sebagai pasar atau pengguna suatu produk atau jasa. Terdapat empat karakteristik yang mempengaruhi pengguna dalam melakukan pembelian menurut Kotler (2003) diantaranya faktor budaya (budaya, sub budaya, dan kelas sosial), faktor sosial (kelompok keluarga, peran, dan status), faktor pribadi (umur, pekerjaan, situasi ekonomi, gaya hidup, dan kepribadian), dan faktor psikologis (pengetahuan, motivasi, keyakinan, dan sikap). Berdasarkan penelitian (Wiliasih \& Shadrina, 2017) ada 6 faktor dominan yang mendorong nasabah untuk menggunakan produk funding lembaga keuangan syariah adalah promosi, pelayanan, kredibilitas lembaga, kesesuaian dengan syariah, lokasi lembaga, dan lingkungan tempat tinggal nasabah. Michael Porter mengatakan strategi merupakan upaya dan langkah-langkah yang digunakan perusahaan untuk mencapai tujuan yang telah ditentukan. Strategi bisnis adalah acuan dan pedoman bagi perusahaan untuk bersaing dan bertahan. Apabila perusahaan yang memilih dan berhasil mengimplementasikan strategi kepemimpinan biaya atau diferensiasi produk, akan berada dalam posisi untuk secara efektif menangani kompetitif kekuatan yang menentukan keberhasilan dalam suatu industri (Wibowo, et. al. 2017)

\section{Metode Penelitian}

Desain yang digunakan pada penelitian ini adalah kombinasi antara deskriptif dan 


\section{At-Taqaddum}

Vol. 12 No. 2 (2020) 183-200

eksperimental. Desain deskriptif menjawab atas pertanyaan-pertanyaan tentang siapa, apa, kapan, di mana dan bagaimana keterkaitan dengan penelitian tertentu. Penelitian deskriptif digunakan untuk memperoleh informasi mengenai status fenomena variabel atau kondisi situasi. Desain eksperimental adalah desain riset yang diterapkan untuk penjajagan atau memperoleh pengetahuan awal. Eksperimen dalam riset sosial tak jarang digunakan untuk mengetahui aspek kausal atau penyebab terjadinya fenomena sosial yang kemudian diaplikasikan kedalam fenomena ekonomi khususnya perbankan syariah di Indonesia.

Metode pengumpulan data yang digunakan pada penelitian ini adalah non communication method, yakni berupa observasi, kajian literatur dan eksperimen. Data yang digunakan pada penelitian ini adalah data sekunder. Data sekunder diperoleh dari instansi-instansi yang terkait dengan objek penelitian. Adapun instansi yang terkait adalah Otoritas Jasa Keuangan, sebagai instansi yang menyajikan data tentang Statistika Perbankan Indonesia dan Statistika Perbankan Syariah di Indonesia. Data yang digunakan mengenai perbandingan total asset perbankan syariah, total Pembiayaan yang Disalurkan (PYD), total Dana Pihak Ketiga (DPK) dan total jaringan kantor bank syariah seluruh Indonesia 2019.

Metode analisis yang digunakan pada penelitian ini adalah studi literatur yang bertujuan untuk menjawab mengapa market share perbankan syariah di Indonesia saat ini masih demikian rendah. Dengan menggunakan berbagai sumber yang dianggap relevan, menggunakan penelitian-penelitan sebelumnya yang sama atau memiliki kemiripan, kemudian juga konsep-konsepnya yang dianggap sesuai, serta dengan membandingkan temuan-temuan empirik didapat yang disesuaikan dengan konteks kekinian peneliti akan mencoba menjawab strategi yang benar-benar dirasa tepat untuk meningkatkan market share perbankan syariah di Indonesia.

\section{Hasil dan Pembahasan}

Perkembangan bank syariah di Indonesia sejak awal di awal tahun 1990-an mengalami perkembangan cukup signifikan, pasca krisis ekonomi di tahun 1998. Bank syariah diyakini sebagai bank yang tahan terhadap krisis dengan Bank Muamalat Indonesia sebagai role model pada saat itu yang mampu bertahan melalui goncangan ekonomi tersebut yang konon kabarnya tanpa Bantuan Likuiditas Bank Indonesia. Pada tahun 2000-an bank syariah telah menarik banyak investor dan masyarakat untuk ikut dalam kancah pembangunan ekonomi negeri. Saat ini sudah dua puluh delapan tahun sejak kehadirannya bank syariah memang telah memiliki jaringan yang cukup luas dengan BUS (Bank Umum Syariah), UUS (Unit Usaha Syariah) dan BPRS (Bank Pembiayaan Rakyat Syariah) nya, namun tidak diimbangi dengan pertumbuhan market share nya.

Ditahun 2006 Bank Indonesia mencanangkan Program Akselerasi Pengembangan Perbankan Syariah pertama kalinya guna mendukung tumbuh kembang perbankan syariah di Indonesia. Melalui siaran pers-nya Biro Humas Bank Indonesia (2006), dalam 
Program Akselerasi Pengembangan Perbankan Syariah, Bank Indonesia (BI) telah menetapkan 6 Pilar, yaitu (i) Penguatan Kelembagaan Bank Syariah, (ii) Pengembangan Produk Bank Syariah, (iii) Intensifikasi Edukasi Publik \& Aliansi Mitra Strategis, (iv) Peningkatan Peranan Pemerintah \& Penguatan Kerangka Hukum Bank Syariah, (v) Penguatan SDM Bank Syariah, dan (vi) Penguatan Pengawasan Bank Syariah. Ditetapkanlah target market share di akhir tahun 2008 oleh Bank Indonesia akan mencapai 5,25\%. Namun target tersebut baru tercapai pada tahun 2016. Data berdasarkan Statistika Perbankan Syariah yang disajikan dalam gambar.

Gambar 1. Perkembangan Market Share Perbankan Syariah di Indonesia Januari 2011-.September 2017(dalam persentase)

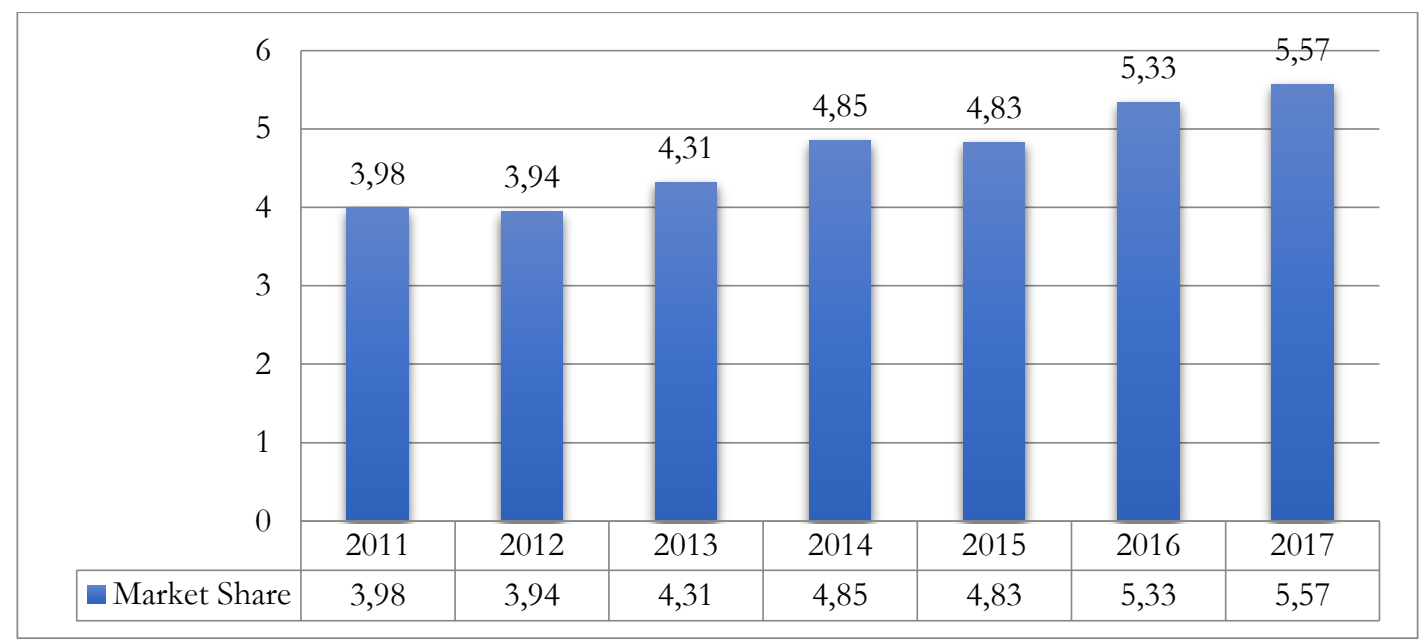

Sumber: Statistik Perbankan Syariah, OJK 2019

Pada tahun 2011, pangsa pasar perbankan syariah hanya sebesar 3,98 persen. Walaupun mengalami pertumbuhan yang fluktuatif, akan tetapi pada September 2017 pangsa pasar perbankan syariah menjadi 5,57 persen. Dari 5,57\% tersebut, 68,08\% diantaranya merupakan market share BUS. Berikutnya terdapat 29,40\% market share UUS, serta BPRS hanya meraih market share sejumlah 2, 52\%.Target market share sebesar 5\% dari asset perbankan nasional baru tercapai selama sepuluh tahun perjalanan yaitu di tahun 2016. angka tersebut bertahan sampai dengan Juni 2019.

\section{Faktor Penyebab Rendahnya Market Share Bank Syariah}

Agustianto dalam (Barmana, 2015) menganalisa ada delapan faktor penyebab rendahnya market share Bank Syariah. Sebagai berikut:

1. Tingkat pemahaman umat tentang Bank Syariah masih sangat rendah. 
2. Tokoh agama tidak memiliki ilmu yang memadai tentang ekonomi Islam (ilmu ekonomi makro-moneter) beberapa juga masih berpandangan miring tentang Bank Syariah.

3. Belum ada gerakan bersama dalam skala besar dalam mempromosikan bank syariah.

4. Terbatasnya pakar dan SDM ekonomi syariah.

5. Peran pemerintah masih relatif kecil dalam mendukung dan mengembangkan ekonomi syariah.

6. Peran ulama, masih relatif kecil. Ulama yang berjuang keras mendakwahkan ekonomi islam masih terbatas pada DSN dan kalangan akademisi tertentu.

7. Para akademisi di perguruan tinggi termasuk perguruan Tinggi Islam belum optimal.

8. Bank Indonesia dan bank-bank syariah belum menemukan strategi jitu dan ampuh dalam memasarkan bank syariah kepada masyarakat luas.

Dalam membahas permasalahan rendahnya market share perbankan syariah di Indonesia, dari berbagai literatur yang ada dikelompokkan menjadi tiga unsur yang tidak terlepas satu sama lain dalam kegiatan operasionalnya ialah (1) Elemen internal bank syariah, (2) Elemen pemerintah dan regulator, dan (3) Elemen masyarakat sebagai pengguna.

\section{Elemen Internal Bank Syariah}

Tidak bisa dipungkiri bahwa kondisi market share perbankan syariah yang seperti ini bisa jadi merupakan cerminan dari kondisi lemahnya kondisi internal bank syariah sendiri, ibarat sebagai ujung tombak dalam sebuah pertarungan bisnis. Ada banyak juga bagian dalam elemen internal bank syariah seperti produk perbankan syariah, permodalan, jaringan kantor pelayanan dan teknologi informasinya, SDI (sumber Daya Insani), serta tata kelola yang baik.

Kelemahan dalam produk bank syariah yang disampaikan oleh pejabat Direktorat Otoritas Jasa Keuangan bernama Dhani Gunawan Idhat (detikfinance, 2015) mengatakan salah satunya yaitu produk yang tidak variatif dan pelayanan yang belum sesuai ekspektasi masyarakat. Fitur bank syariah belum selengkap produk serupa bank konvensional. Sehingga masih banyak kebutuhan dari transaksional masyarakat pebisnis dan pengguna jasa layanan keuangan di Indonesia masih belum terlayani. Kemudian Idhat juga menambahkan Bank syariah juga harus mampu mengeluarkan produk-produk atau jasa yang mampu memenuhi harapan publik. Dari sisi syariah misalnya, itu tidak cukup. Kemudian dari sisi kecepatan pelayanan, dari sisi kenyamanan. Keunggulan kompetitif ini akan muncul apabila bank syariah, memiliki keunikan yang benar-benar bisa dirasakan oleh masyarakat (Sharianews.com, 2018).

Elemen internal mengapa market share bank syariah sulit berkembang selanjutnya adalah modal. Faktor utama kenapa perbankan syariah sulit berkembang adalah karena permodalan yang terbatas. Oleh karenanya kehadiran investor baru akan menjadi angin 
segar bagi perbankan syariah. Pasalnya, bank syariah membutuhkan modal baru untuk meningkatkan ekspansi aset, pembiayaan dan dana pihak ketiga (DPK) di tahun-tahun mendatang jelas Adiwarman Azwar Karim menyampaikan (m.kontan.co.id, 2017). Faktor modal juga berdampak pada faktor jaringan kantor pelayanan juga teknologi informasi yang dipakai di mana penduduk Indonesia tersebar di berbagai pelosok kawasan Nusantara yang sangat luas wilayahnya. Dampak dari minimnya permodalan adalah kurang leluasanya bank syariah dalam membuka kantor cabang, mengembangkan infratruktur, dan mengembangkan segmen layanan yang memiliki karakteristik risiko lebih bervariasi, termasuk sejumlah layanan bank yang hanya dapat dilakukan oleh bank kategori BUKU 3 dan 4 seperti kustodian, digital money, dan trustee. Keterbatasan dalam pengembangan usaha tersebut mengakibatkan perbankan syariah kesulitan dalam meningkatkan tingkat efisiensi operasionalnya (Fauzi, 2016).

Ekspansi perbankan syariah yang tinggi ternyata tidak diikuti oleh penyediaan SDI secara memadai sehingga secara akumulasi diperkirakan menimbulkan gap mencapai 20.000 orang. Hal ini dikarenakan masih sedikitnya lembaga pendidikan (khususnya perguruan tinggi) yang membuka program studi keuangan syariah. Selain itu, kurikulum pendidikan dan materi pelatihan di bidang keuangan syariah juga belum terstandarisasi dengan baik untuk mempertahankan kualitas lulusannya (Alamsyah, 2015).

Setidaknya para praktisi perbankan syariah memiliki dua tanggung jawab (i) Sebagai penyiar bank syariah dan (ii) Sebagai pemasar bank syariah. Karena memang masyarakat sebelum menjadi nasabah harus di edukasi. Edukasi ini yang menjadi kunci keberhasilan positioning bank syariah bisa menempati hati dan benak masyarakat secara tepat. Kurangnya pemahaman tentang ekonomi islam dari para praktisi akan berakibat gagal paham juga terhadap masyarakat sebagai customer. Juga kurang perdulinya para praktisi perbankan syariah mengenai arti dari kaaffah atau menyeluruh atau totalitas. Ketika dirinya memang sudah menjadi karyawan bank syariah terlebih adalah sebagai pemasar dari produk bank syariah, dirinya adalah sebagai role model atau panutan bagi customer-nya. Sehingga ketika berhadapan dengan nasabah dia tidak punya pilihan lain selain menjual produk syariah dimana dia sendiri hanya menggunakan bank syariah sebagai sarana utama bahkan satu-satunya dalam transaksi ekonomi dirinya dan keluarga.

Konsep ibda' binnafsib atau dimulai dari diri sendiri dapat memberi keyakinan lebih kepada masyarakat luas mengenai apa yang dia bawakan. Sebagai analoginya adalah seorang yang mengkampanyekan "Gerakan Anti Rokok" sedangkan dirinya sendiri adalah perokok. Ini adalah sesuatu yang tidak mungkin dalam sebuah framing sebab akibat. Menyuarakan kebiasaan tidak merokok disaat yang sama dirinya menghisap rokok. Sama halnya dengan seorang pegawai bank syariah, dimana dirinya adalah penggiat "Gerakan Anti Riba". Namun kenyataan yang ada saat ini adalah banyak sekali karyawan bank syariah yang tetap memakai produk dari bank bukan syariah. Dan ini justru semakin melemahkan posisi tawar dalam berhadapan dengan masyarakat yang cukup kritis dewasa ini.

Tata kelola yang baik atau good corporate governance syariah akhir-akhir ini menjadi faktor yang cukup menarik diperbincangkan dikalangan praktisi dan pengamat ekonomi syariah. Banyak bank syariah mengalami kinerja menurun diakibatkan naiknya NPF (Non- 
Performance Financing). Lahirnya NPF ini berawal dari tata kelola yang keluar dari yang seharusnya. Kegagalan bank syariah yang paling mendasar adalah menyangkut tata kelola dan mengelola risiko. Banyak bank syariah jatuh pada lubang yang sama, yaitu menyangkut tata kelola dan tergoda hendak membiayai apa yang dibiayai oleh bank konvensional.

\section{Elemen Pemerintah dan Regulator}

Hal pertama permasalahan adalah belum selarasnya visi dan kurangnya koordinasi antar pemerintah dan otoritas dalam pengembangan perbankan syariah. Kedua, pengaturan dan pengawasan yang masih belum optimal. Ketiga, Kurangnya support dan dukungan pemerintah terhadap pengembangan perbankan syariah, terutama jika dibandingkan dengan negeri Jiran (Rusydiana, 2016).

Banyak peneliti ketika berbicara tentang faktor legal atau structural ini terutama pemerintah, banyak membandingkan dengan negara-negara pengusung ekonomi syariah seperti Malaysia, Iran dan negara-negara Timur Tengah lainnya. Namun lagi-lagi keberpihakan pemerintah dalam bentuk dukungan regulasi dan penempatan dana merupakan faktor yang tidak dinikmati oleh perbankan syariah Indonesia. Sementara pada sisi laintantangan ke depan untuk mempercepat peningkatan penguasaan pasar diperkirakan tidak semakin mudah. Pemerintah Malaysia memilih untuk ambil peranan yang sangat pro-aktif dalam penerapan kebijakan orientasi pengembangan dan pemakaian hukum sebagai instrumen perubahan dan kontrol sosial. Pemerintah Malaysia di tahun 2003 mengkonversi Bank Rakyat-nya yang sejak tahun 1993 memiliki 4 cabang syariah melalui kebijakannya merubah menjadi syariah secara total. Political will pemerintah Malaysia demikian kuat sehingga memerintahkan perusahaan BUMN untuk mengalihkan dananya ke bank syariah. Oleh karenanya sebagian besar dana yang terkumpul di bank syariah Malaysia adalah dana perusahaan BUMN.

Iran yang merupakan negara yang memiliki asset perbankan syariah terbesar dunia, dan memang karena negara berdasarkan agama, pemerintahnya pun memberikan dukungan penuh dengan mengundangkan. Undang-Undang di tahun 1983 yang mewajibkan bank-bank di Iran untuk dalam tempo tiga tahun mengubah secara menyeluruh kegiatan usaha mereka sesuai dengan prinsip syariah dan mengubah simpanan nasabah yang berdasarkan bunga (outstanding interest-based deposits) menjadi simpanan yang bebas bunga dalam kurun waktu satu tahun sejak undang-undang tersebut diundangkan (Syihabuddin, 2012). Sedang di Indonesia pemerintah cenderung mengambil sikap memberi kebebasan kepada masyarakat untuk menentukan sendiri pilihan layanan transaksional nya (market driven). Padahal Adiwarman Karim dalam (Syihabuddin, 2012) berpendapat bahwa industri perbankan syariah yang di tahun 2012 market share 3\% saja sudah masuk peringkat empat besar di dunia. Ini menggambarkan bahwa Indonesia akan mampu memimpin industri keuangan syariah global. Jika market share perbankan syariah Indonesia 15\% saja sudah barang tentu menjadi yang terdepan dalam industri keuangan syariah dunia.

Posisi Indonesia menurut Otoritas Jasa Keuangan dalam Roadmap 2017-2019 
pada tahun 2016 turun menjadi urutan ke-10 dibawah Bangladesh untuk total aset perbankan syariah. Ini menjadi tantangan menarik bagi pemerintah dan regulator untuk segera ambil langkah strategis guna menyikapinya.

\section{Elemen masyarakat}

Kondisi market di Indonesia terbagi menjadi dua, yaitu masyarakat religius dan masyarakat realistis. Masyarakat religius cenderung melihat segala sesuatu dari sisi agama terlebih dahulu. Apa yang diperintahkan oleh agamanya, maka itulah dianggap yang terbaik bagi dirinya dan kehidupannya. Namun berbeda dengan masyarakat realistis yang cenderung melihat segala sesuatu dari pertimbangan ekonomis, sesuatu hal tersebut mendatangkan keuntungan bagi dirinya atau tidak. Disinilah dibutuhkan kemampuan untuk melihat bahwa bank syariah tidak hanya semata perintah agama saja, namun dalam Islam segala sesuatu perintah pasti didasarkan pada dua dasar pemikiran. Yaitu sesuai dengan perintah agama, ada perintah atau dalil nya (naqliyab) dan pasti sesuai dengan kebutuhan juga logis secara dasar pemikiran akal (aqliyah).

Kurangnya pemahaman atau literasi masyarakat mengenai jasa perbankan syariah. Dari data Survey Nasional Literasi Keuangan Otoritas Jasa Keuangan di tahun 2013 hanya sekitar $22 \%$ dari penduduk Indonesia yang memahami jasa pelayanan perbankan, dan $57 \%$ dari penduduk saja yang sudah memakai jasa perbankan. Ini data total perbankan di Indonesia, artinya adalah betapa rendahnya pemahaman dari masyarakat mengenai bank syariah jika total masyarakat yang belum paham jasa perbankan masih sekitar 78\%. berdasarkan hasil survey nasional yang dilakukan Otoritas Jasa Keuangan (OJK) pada 2016, indeks literasi keuangan syariah hanya 8,11 persen. Dibandingkan dengan jumlah penduduk muslim di Indonesia yang berada di atas 200 juta jiwa, maka persentasi 8,11 persen tentulah sangat minim.

Keluarnya Fatwa Majelis Ulama Indonesia Nomor 1 tahun 2004 tentang Bunga (Interest/Faidah) yang berisi tentang haram-nya praktik pembungaa-an uang yang dapat dikategorikan sebagai riba yang sangat jelas dilarang dengan keras didalam Al-Quran belum seluruhnya difahami oleh masyarakat, bahkan banyak sekali yang tidak faham. Selain itu masih banyak masyarakat yang tidak mengikuti pendapat Majelis Ulama Indonesia tersebut. Kondisi ini terjadi karena masyarakat mengikuti pendapat ustadz/ulama lain yang tidak sependapat dengan Majelis Ulama Indonesia (baik NU maupun Muhammadiyah) (Ghafur W, 2008).

Masyarakat yang teredukasi dengan baik mengenai dasar ekonomi Islam akan tahan terhadap isu-isu negatif terhadap bank syariah dan operasionalnya. Dimana kita ketahui saat ini perbankan syariah banyak mendapat prasangka negatif, pandangan-pandangan miring, yang cukup menjadi sorotan perhatian, dan sedikit banyak mempengaruhi perkembangan dari bank syariah itu sendiri. Yang menarik bukan dari kalangan yang berbeda keyakinan, namun justru datang dari kalangan sebagian ummat Islam sendiri. Inilah tantangan yang harus disikapi perbankan syariah dengan langkah strategis merangkul semua pihak, baik praktisi, pemerintah, regulator, dan ulama yang berkompeten baik paham alur perbankan juga paham ilmu syariatnya, untuk bertemu, 


\section{At-Taqaddum}

Vol. 12 No. 2 (2020) 183-200

bermusyawarah jika ada hal yang harus dipecahkan bersama. Dengan aktif bertemu dan membahas masalah-masalah seputar perbedaan, bukan tidak mungkin semua isu-isu negatif mengenai bank syariah akan teratasi dengan baik. Adanya DSN-MUI (Dewan Syariah Nasional - Majelis Ulama Indonesia) yang memiliki Visi yaitu "memasyarakatkan ekonomi syariah dan mensyariahkan ekonomi masyarakat", serta memiliki Misi yaitu "menumbuh-kembangkan ekonomi syariah dan lembaga keuangan/bisnis syariah untuk kesejahteraan umat dan bangsa" dimana pengurusnya terdiri dari para pakar dengan latar belakang disiplin keilmuan ekonomi dan fiqh Islam, serta praktisi LKS dan perwakilan regulator yang kapasitas keilmuannya tidak perlu diragukan lagi dalam memutus segala sesuatu mengenai kemaslahatan bank syariah. Sehingga edukasi untuk percaya kepada para ulama yang patuh kepada asas legal formal juga perlu digaungkan.

\section{Strategi Meningkatkan Market Share Perbankan Syariah}

Untuk meningkatkan market share perbankan syariah di Indonesia diperlukan upaya yang komprehensif dan strategis sebagai berikut:

\section{Strategi Elemen Internal Bank Syariah}

Strategi peningkatan market share dari internal bank syariah ialah pembenahan dan optimalisasi produk perbankan syariah, permodalan, jaringan kantor pelayanan dan teknologi informasinya, SDI (sumber Daya Insani), serta tata kelola yang baik. Produkproduk yang ada pada bank syariah harus di upgrade sehingga tidak hanya melayani jenis usaha yang ada pada jenis usaha BUKU 1 (Bank Umum Kegiatan Usaha-Satu) dan BUKU 2 (Bank Umum Kegiatan Usaha-Dua) sehingga juga dapat melayani transaksi seperti bank kustodian, digital money, dan trusty yang hanya ada pada bank BUKU 3 dan BUKU 4. Untuk mencapai kesetaraan dengan Bank Umum Konvensional, bank syariah harus dapat menciptakan sebuah terobosan produk yang dapat di akses oleh kalangan menengah keatas, diversifikasi produk mikro, dan juga pengembangan pelayanan sektor korporasi. Berikutnya adalah inisiasi syariah pada investment bank dimana mengutamakan pembiayaan proyek-proyek pemerintah, sehingga dengan demikian proyek dengan dana besar akan terserap oleh bank syariah (OJK, 2015). Dengan demikian dibutuhkan kualitas layanan juga kemampuan serta knowledge dari praktisi bank syariahnya.

Selain sektor produktif, kontribusi lain yang bisa dilakukan perbankan syariah dalam mendukung pemerataan ekonomi adalah dengan penguatan kewirausahaan dan financial inclusion kepada kelompok masyarakat yang belum tersentuh sektor keuangan. Bila aktivitas wirausaha semakin kuat dan financial inclusion mencapai puncaknya, akan menunjukkan bahwa ekonomi syariah memiliki sistem perekonomian yang mampu mengangkat kesejahteraan umat (Ibrahim, 2013). Dalam rangka mendukung pengembangan keberagaman produk dan kualitas layanan perbankan syariah (OJK, 2015) melalui: 
1. Peningkatan peran WGPS (Working Group Perbankan Syariah) dalam pengembangan produk perbankan syariah.

2. Pengembangan instrumen pendanaan/investasi alternatif berbasis bagi hasil dan produk pengelolaan investasi sesuai life cycle nasabah.

3. Pengembangan instrumen likuiditas syariah dan manajemen risiko (termasuk instrumen bedging).

4. Penyempurnaan ketentuan produk dan aktivitas baru.

5. Peluncuran produk tabungan syariah untuk pelajar

6. Pengembangan dan penyempurnaan standar produk (termasuk dokumentasi) bank syariah sesuai karakteristik usaha

7. Kegiatan peningkatan service excellence dan kustomisasi produk sesuai perkembangan preferensi konsumen.

Dari sisi permodalan, bank syariah diharapkan untuk lebih aktif mengupayakan tambahan modal kepada pemilik, menawarkan kepada investor publik dengan sasaran masyarakat berpenghasilan menengah keatas dan juga aktif mencari strategic partner atau investor dengan kapasitas besar. Yang tujuannya adalah meningkatkan modal bank syariah menjadi BUKU 3 (Bank Umum Kegiatan Usaha-3) yaitu bank umum dengan modal inti diatas Rp. 5 Trilyun sampai dengan Rp. 30 Trilyun dan BUKU 4 (Bank Umum Kegiatan Usaha-4) bank umum dengan modal inti diatas Rp. 30 Trilyun. Dengan Memperbaiki struktur dana untuk mendukung perluasan segmen pembiayaan. Arah kebijakan Otoritas Jasa Keuangan yang dapat ditempuh meliputi enam program kerja prioritas sebagai berikut:

1. Optimalisasi pengelolaan dana haji melalui perbankan syariah.

2. Rekomendasi dan fasilitasi adopsi model pembiayaan mikro perbankan syariah sesuai kebutuhan pemerintah dan sektor ekonomi prioritas.

3. Optimalisasi pengelolaan dana wakaf, zakat, infaq dan shadaqah sekaligus peningkatan integrasi fungsi sosial dalam kegiatan usaha bank syariah.

4. Mendorong keterlibatan bank syariah dalam pengelolaan dana pemerintah pusat/daerah dan dana BUMN/BUMD.

5. Mendorong penempatan dana hasil emisi sukuk pada bank syariah.

6. Perumusan kerangka insentif perluasan pembiayaan produktif sektor corporate\&long term (infrasructure).

Logika yang cukup menarik mengenai modal adalah ketika ingin meningkatkan market share pebankan syariah di Indonesia secara signifikan adalah dengan konversi. Dengan konversi bank konvensional menjadi bank syariah artinya mengkonversi modal konvensional menjadi syariah, dan ini terbukti signifikan meningkatkan asset serta market share perbankan syariah secara simultan di berbagai negara yang sudah melaksanakannya. Dan untuk modal ini jika kita melihat dari sisi hukumnya secara kaidah hukum fiqih seharusnya sudah tidak ada lagi keraguan. Hukum modal bank syariah bisa dibuktikan dari istilah (tertulis), lanjut dengan alur, maksud dan makna. Bukti tertulis dari alur 


\section{At-Taqaddum}

Vol. 12 No. 2 (2020) 183-200

sumber modal bank syariah adalah nama chart of account (COA) atau istilahnya bernama modal atau penyertaan atau sejenisnya, bukan berjudul pendapatan bunga atau pendapatan riba. Istilah COA modal tersebut menentukan alurnya. Alur akuntansi modal secara legal formal akan menyebabkan fungsinya (maksud dan maknanya) sebagai modal, bukan pendapatan riba. Dengan demikian, ditinjau dari sisi istilah, alur, maksud dan maknanya, pos modal terhukum halal, sampai modal tersebut ditransaksikan haram (Sholihin \& Zahra, 2018).

Dengan modal yang berkembang tersebut diharapkan juga dapat mengembangkan cakupan wilayah kerja serta pelayanan kepada masyarakat di wilayah Indonesia, juga diharapkan dengan kecenderungan perubahan era industri 4.0 ini dimana digitalisasi perbankan tidak terelakkan, bank syariah mampu mempersiapkan teknologi layanan termasuk informasi keuangan dengan sistem yang sesuai dengan kebutuhan kekinian. Disisi SDI (Sumber Daya Insani), strategi optimalisasi menurut Otoritas Jasa Keuangan adalah sebagai berikut:

1. Pengembangan standar kurikulum perbankan syariah di perguruan tinggi.

2. Pemetaan kompetensi dan kajian standar kompetensi bankir syariah serta riview kebijakan alokasi anggaran pengembangan SDM bank.

3. Pengembangan program sertifikasi profesi maupun program pengembangan SDM lainnya bagi perbankan syariah bekerjasama dengan lembaga pendidikan menengah dan tinggi atau konsultan perbankan.

4. Program Technical Assistance (TA) kepada bankir syariah untuk aktivitas / sektor bernilai tambah tinggi /prioritas/strategis

Selain itu praktisi bank syariah yang handal adalah praktisi yang mampu berusaha untuk kaaffah terhadap keyakinannya sebagai role model dan ujung tombak membumikan ekonomi syariah di Indonesia. Sumber Daya Insani yang mampu mulai dari dirinya sendiri untuk hanya memakai jasa layanan bank syariah saja. Kemudian mampu terus memahami dan mempelajari ilmu ushul fiqib (Solihin, 2019) karena hanya dengan kemampuan lengkap, kombinasi antara ilmu ekonomi perbankan pada umumnya, juga harus paham ilmu perbankan syariah, ekonomi syariah dan ilmu fiqih tersebut praktisi perbankan syariah bisa memahami konteks serta kondisi pemahaman keberagamaan yang beraneka ragam yang ada di Indonesia.

Tata kelola yang baik bagi perbankan syariah tentu berbeda dengan tata kelola bank konvensional, karena tujuan akhir dari aktivitas bank syariah tidak dapat dilepaskan dari maqasid syariah, adalah tujuan utama yang ingin diwujudkan oleh syariah. Menurut Imam Asy-Syatibi tujuan utama syariah adalah mencegah kemudharatan dan mendatangkan kemaslahatan, yang ke-duanya dilaksanakan dengan ad-dharuuriyyat alkhams, penjagaan terhadap lima hal dasar yaitu: (1) Agama, (2) Jiwa, (3) Harta, (4) Nasab atau keturunan, dan (5) Akal.

Pelaksanaan tata kelola yang baik dalam industri perbankan syariah masih merupakan salah satu upaya untuk melindungi kepentingan stakeholders dan meningkatkan kepatuhan terhadap peraturan perundang-undangan yang berlaku serta 
nilai-nilai etika yang berlaku secara umum serta prinsip syariah. Berdasarkan sistem hukum Indonesia, prinsip-prinsip syariah yang terkandung dalam Qur'an dan hadist ini diterjemahkan dalam Fatwa yang dikeluarkan oleh Dewan Syariah Nasional, yang selanjutnya menjadi sumber dalam pembentukan perundang-undangan yang mengatur aktivitas keuangan syariah di Indonesia. Implementasi tata kelola yang terintegrasi melalui fungsi pemerintah dan otoritas, kesiapan infrastruktur legal, peran Dewan Pengawas Syariah dan tingginya tingkat pemahaman masyarakat, dapat mendorong percepatan pertumbuhan perbankan syariah Indonesia (Abubakar \& Handayani, 2017).

\section{Strategi Elemen Pemerintah dan Regulator}

Strategi peningkatan market share dari elemen pemerintah dan regulator adalah Memperkuat sinergi kebijakan antara otoritas, pemerintah, dan stakeholder lainnya. Arah kebijakan ini dijabarkan dalam bentuk lima program kerja prioritas (Otoritas Jasa Keuangan, 2015) sebagi berikut:

1. Mendorong pembentukan Komite Nasional Pengembangan Keuangan Syariah RI.

2. Peningkatan kerja sama antara regulator dengan perguruan tinggi / lembaga riset domestik maupun internasional dalam rangka sinergi kebijakan perbankan syariah termasuk dalam rangka perumusan dan operasional fatwa.

3. Implementasi forum kerja sama dengan lembaga negara / pemerintah dalam rangka penyusunan referensi hukum dan peraturan perundangan yang lebih mengakomodasi prinsip syariah.

4. Mendorong pembentukan pusat riset dan pengembangan perbankan dan keuangan syariah.

5. Menginisiasi dan mengembangkan sharia investment bank, terutama dalam rangka pembiayaan proyek-proyek pemerintah.

Beberapa negara yang didukung penuh oleh pemerintahnya, mengalami pertumbuhan dan perkembangan yang cukup pesat, tidak hanya bisa bersaing dengan perbankan konvensional, tetapi juga mampu menjadi perbankan syariah terbesar, seperti Iran dan Malaysia yang menduduki urutan pertama dan kedua di industri keuangangan syariah global. Sementara Turki dan Sudan yang dukungan pemerintah setengah hati, kemajuan perbankan syariah tidak begitu signifikan. Adiwarman Karim dalam (Syihabuddin, 2012) berpendapat bahwa industri perbankan syariah yang di tahun 2012 market share 3\% saja sudah masuk peringkat empat besar di dunia. Dan ini menggambarkan bahwa Indonesia akan mampu memimpin industri keuangan syariah global. Jika market share perbankan syariah Indonesia $15 \%$ saja sudah barang tentu menjadi yang terdepan dalam industri keuangan syariah dunia.

Untuk menjawab tantangan keuangan dan ekonomi syariah di Indonesia, pemerintah membentuk Komite Nasional Keuangan Syariah (KNKS) melalui Peraturan Presiden Nomor 91 Tahun 2016 tentang Komite Nasional Keuangan Syariah. Komite ini 


\section{At-Taqaddum}

Vol. 12 No. 2 (2020) 183-200

dipimpin langsung oleh Presiden RI dan Wakil Presiden RI, kemudian ada Dewan Pengarah yang beranggotakan sepuluh pimpinan dari unsur pemerintahan dan otoritas terkait, yaitu Menteri Koordinator Bidang Perekonomian, Menteri Perencanaan Pembangunan Nasional/Kepala Badan Perencanaan Pembangunan Nasional, Menteri Keuangan, Menteri Agama, Menteri Badan Usaha Milik Negara, Menteri Koperasi dan Usaha Kecil Menengah, Ketua Dewan Komisioner Otoritas Jasa Keuangan, Gubernur Bank Indonesia, Ketua Dewan Komisioner Lembaga Penjamin Simpanan, dan Ketua Umum Majelis Ulama Indonesia. Tugas-tugas komite selanjutnya dilaksanakan oleh manajemen eksekutif (Kemenkominfo, 2017).

Ditangan pemerintah dan regulator-lah makna mujaddid secara ekonomi ini dimaknai sebagai yang membawa pembaruan dan tidak dapat dapat dilaksanakan oleh setiap orang kecuali seseorang yang memegang amanah sebagai pemerintah atau regulator. Dan ini tidak akan mudah kecuali dilakukan dengan upaya yang sungguhsungguh dan niat yang kuat.

\section{Strategi Elemen Masyarakat}

Strategi peningkatan market share dari elemen masyarakat menurut Otoritas Jasa Keuangan adalah lima program kerja guna meningkatkan literasi dan preferensi masyarakat diantaranya yaitu:

1. Penyelenggaraan PRS (Pasar Rakyat Syariah).

2. Program Islamic Banking (iB) campaign terhadap produk perbankan syarlah dan program penguatan positioning, differentiation, branding (PDB) perbankan syariah.

3. Memperkuat kolaborasi dengan Edukasi dan Perlindungan Konsumen (EPK) dan stakeholder utama dalam peningkatan literasikeuangan syariah.

4. Program sosialisasi perbankan syariah (iB) bagi key opinion leaders.

5. Sosialisasi untuk meningkatkan peran BPRS dalam pengelolaan dana pemerintah pusatldaerah untuk pemberdayaan sektor riil bersama Lembaga Keuangan Mikro Syariah (LKMS) lalnnya.

Memaksimalkan sosialisasi Perbankan Syariah di masyarakat secara lengkap juga dapat menigkatkan efektifitas dari kinerja Perbankan Syariah. Dengan masyarakat sudah memiliki pengetahuan serta pemahaman yang baik mengenai Perbankan Syariah dan ekonomi Indonesia, maka masyarakat tidak perlu ragu terhadap kinerja Perbankan Syariah. Sehingga, market share Bank Syariah akan lebih meningkat. Sosialisasi juga dapat dilaksanakan dengan mengembangkan jaringan kelembagaan dengan berbagai institusi yang mendukung Perbankan Syariah, baik lembaga formal maupun informal. Lembagalembaga seperti Masyarakat Ekonomi Syariah (MES) dan Pusat Komunikasi Ekonomi Syariah (PKES) dapat menjadi partner bagi sosialisi sistem bagi hasil dalam produk mudharabah dan musyarakah. Dengan jaringan ini maka sosialisasi sistem bagi hasil dalam Perbankan Syariah akan semakin efektif (Barmana, 2015). 


\section{Kesimpulan}

Terdapat tiga dimensi yang menjadi pembeda antar elemen yang didalamnya juga terdapat unsur-unsur pendukung. Yaitu (1) strategi untuk elemen internal perbankan syariah, (2) strategi untuk elemen pemerintah dan regulator, dan (3) strategi untuk elemen masyarakat. Untuk mendukung pertumbuhan market share perbankan Syariah diharapkan perbankan syariah dapat segera mendapatkan akses permodalan yang pada akhirnya dapat menaikkan utilitas dan kemampuan bersaing, pemerintah dan regulator mempertimbangkan untuk segera ambil langkah nyata strategis untuk pembentukkan Bank Syariah Milik Negara, karena dengan logika permodalan, hanya dengan peran dari pemerintah dan regulatorlah, secara signifikan akan meningkatkan market share perbankan syariah di Indonesia. Disamping itu, masyarakat juga perlu membuka hati dan pikiran untuk mau meningkatkan pengetahuan, memahami ekonomi syariah beserta dasar pengenaan hukumnya. Dengan memahaminya maka paling tidak terbentuk individu yang akan selalu mawas diri menjaga aliran keluar masuk keuangan pribadinya dari hal yang diharamkan agama.

\section{Daftar Pustaka}

Abubakar, Lastuti., dan Handayani, Tri. 2017. Percepatan Pertumbuhan Perbankan Syariah Melalui Implementasi Tata Kelola Syariah. Jurnal Law and JusticeVol. 2 No. $2: 124-134$.

Asmoro, Wahyu Probo. 2018. Analisis Faktor-Faktor Yang Mempengaruhi Market Share Bank Syariah Di Indonesia. Program Sarjana. Universitas Islam Negeri Syarif Hidayatullah, Jakarta.

Bank Indonesia. 2005. Peraturan Bank Indonesia Nomor.7/46/PBI/2005.Penjelasan Atas Peraturan Bank Indonesia Nomor: 7/46/PBI/2005 Tentang Akad Penghimpunan Dan Penyaluran Dana Bagi Bank Yang Melaksanakan Kegiatan Usaha Berdasarkan Prinsip Syariah, November 14:3.

Bank Indonesia, Siaran Pers. Direktorat Perencanaan Strategis dan Biro Hubungan Masyarakat. $\quad$ https://www.bi.go.id/id/ruang-media/siaranpers/pages/sp 86306.aspx. Diakses pada tanggal 20 Mei 2019.

Bank Indonesia. Biro Hubungan Masyarakat. 2012. Perkembangan dan Prospek Perbankan Syariah Indonesia: Tantangan Dalam Menyongsong MEA 2015. Disampaikan oleh Dr. Halim Alamsyah Deputi Gubernur Bank Indonesia pada Ceramah Ilmiah Ikatan Ahli Ekonomi Islam (IAEI), Milad ke-8 IAEI, 13 April 2012.

Barmana, Muhammad Andira. 2015. Peningkatan MSS (Market Share Of Sharia) Dalam 


\section{At-Taqaddum}

Vol. 12 No. 2 (2020) 183-200

Menghadapi MEA (Masyarakat Ekonomi Asean) 2015 Melalui IM (Islamic Microfinance ) Dan IB (Islamic Banking) Di Indonesia. Jurnal Penulis Muda.https:// www.medinaconsulting.co.id/assets/media/file/ file-peningkatan-mss-marketshare-of-sharia-dalam-menghadapi-mea-masyarakat-ekonomi-asean-2015-melalui-im-islamicmicrofinance-dan-ib-islamic-banking-di-indonesia.pdf

Fauzi, Gustani. 2016. Program Sarjana. IAIN Tulungagung, Jawa Timur. Kinerja Dan Langkah Strategis Pengembangan Perbankan Syariah Di Indonesia. Prodi Keuangan \& Perbankan Syariah, Fakultas Syariah, Universitas Islam Bandung. Prosiding Keuangan dan Perbankan Syariah. Volume 2, No.1: 517-522)

Ghafur W, Muhammad. 2008. Pengaruh Fatwa MUI Tentang Keharaman Bunga/Interest Terhadap Perkembangan Perbankan Syariah di Indonesia. Jurnal Penelitian Agama, Vol. XVII. No. 2: 355-371)

Ibrahim, Zaini. 2013. Strategi Mendorong Pertumbuhan Bank Syariah Di Indonesia. Jurnal di https://www.researchgate.net/publication/329211838_STRATEGI_MENDOR ONG_PERTUMBUHAN_BANK_SYARIAH_DI_INDONESIA.

Idhat, Dhani Gunawan, 2015. 7 Hambatan yang Buat Bank Syariah Lambat Berkembang di RI, https://finance.detik.com/moneter/d-3076959/7-hambatan-yang-buatbank-syariah-lambat-berkembang-di-ri. Diakses pada 25 Mei 2019.

Idhat, Dhani Gunawan, 2018. Perbankan Syariah Ada Gaungnya, Tetapi Belum "Nendang”https://sharianews.com/posts/perbankan-syariah-ada-gaungnyatetapi-belum-nendang Diakses pada 25 Mei 2019.

Kotler, Philip.2003. Manajemen Pemasaran. Edisi kesebelas, Jakarta: Indeks kelompok Gramedia.

MA, Ibrahim. 2018. Metode Penelitian Kualitatif - Panduan Penelitian Beserta Contoh Proposal Kualitatif. Penerbit Alfabeta Bandung.

Otoritas Jasa Keuangan 2015, Roadmap Perbankan Syariah Indonesia 2015 - 2019.

Otoritas Jasa Keuangan. 2017. Snapshot Perbankan Syariah Indonesia Posisi 30 September 2017.

Otoritas Jasa Keuangan. 2018. Snapshot Perbankan Syariah Indonesia Posisi Desember 2019.

Rusydiana, Aam Slamet. 2016. Analisis Masalah Pengembangan Perbankan Syariah Di Indonesia: Aplikasi Metode Analytic Network Process. Esensi: Jurnal Bisnis dan Manajemen. Vol. 6 No.2. Oktober 2016 P-ISSN: 2087-2038; E-ISSN:2461-1182 $: 237-246$.

Sholihin, Ahmad Ifham., Az Zahra, Zukhrufah. 2019. Menjawab Tudingan Miring Pada Bank Syariah. Ahmad Ifham Sholihin Press. 
Sodikin, M. (2020). Competitive Advantages of Sharia Banks : Role of Ihsan Behavior and Digital Marketing in New Normal. Journal of Digital Marketing and Halal Industry, 2(1), 114. https://doi.org/http://dx.doi.org/10.21580/jdmhi.2020.2.1.5769

Syihabuddin. 2012. Peran Pemerintah Dalam Pengembangan Perbankan Syariah Di Indonesia. Economic: Jumal Ekonomi dan Hukum Islam, STIAI Darul Ulum Banyuwangi. Vol. 2, No.1: 72-89.

Wibowo, SSA., Handayani, Y., dan Lestari, AR. 2017. Strategi Bersaing Perusahaan Dan Kinerja Perusahaan. Jurnal Riset Akuntansi dan Keuangan Indonesia. Vol. 2. No. 2: 143-150).

Wiliasih, Ranti., dan Shadrina, Fathia. 2017.Faktor Dominan Yang Memengaruhi Keputusan Nasabah Untuk Menabung Di Bank Syariah, BPRS, Dan KSPPS. Jurnal Nisbah, Vol. 3 No. 2: 442-461. 
At-Taqaddum

Vol. 12 No. 2 (2020) 183-200

$200 \mid \mathrm{P}$ a g e 